\title{
Sustaining Lake Toba's Tourism: Role of Creative Industry, Green Tourism Marketing and Tourism Experience
}

\author{
Prihatin Lumbanraja*, Arlina Nurbaity Lubis and Beby Kendida Hasibuan
}

\begin{abstract}
Manuscript type: Research paper.

Research aims: This study aims to investigate the role of creative industry, green tourism marketing and tourist experience in building tourists' satisfaction.

Design/Methodology/Approach: Data were collected from 200 tourists who visited Lake Toba, Indonesia; and then analysed using structural equation modelling.

Research findings: The findings indicate that green tourism marketing and creative industry are positively related to tourism experience. This study, however, does not find substantial evidence to support the direct relationship between green tourism marketing and creative industry with tourism satisfaction. Instead the relationship is mediated by tourism experience.

Theoretical contribution/Originality: The findings indicate that green tourism marketing and creative industry are positively related to tourism experience. This study, however, does not find substantial evidence to support the direct relationship between green tourism marketing and creative industry with tourism satisfaction. Instead the relationship is mediated by tourism experience.
\end{abstract}

* Corresponding author: Prihatin Lumbaraja is a Lecturer at the Management Department, Faculty of Economics and Business, Universitas Sumatera Utara, Medan, Indonesia. Email: titinlumbanraja@yahoo.com

Arlina Nurbaity Lubis is a Lecturer at the Management Department, Faculty of Economics and Business, Universitas Sumatera Utara, Medan, Indonesia. Email: arlinalubis10@gmail.com Beby Kendida Hasibuan is a Lecturer at the Management Department, Faculty of Economics and Business, Universitas Sumatera Utara, Medan, Indonesia. Email: bebykendida08@gmail.com

Acknowledgement: The authors declare that this research was fully funded by Universitas Sumatera Utara, under grant reseach of Non PNBP Talenta USU 2017.

https://doi.org/10.22452/ajba.vol12no1.9 
Practitioner/Policy implications: This study provides insights for marketers and policy makers to better understand how tourism in Lake Toba can be sustained. It specifically highlights the role of creative tourism and green tourism marketing in creating exciting tourism experience and tourism satisfaction. This outcome is expected to facilitate tourism operators in sustaining their businesses and for policy makers to consider this as a strategy for decision-making.

Research limitation: Since this study focusses on the Lake Toba tourism industry only, the generalisability of the findings may be biased. Therefore, future studies should incorporate a larger and more diverse set of samples.

Keywords: Tourism Satisfaction, Tourism Experience, Creative Industries, Green Tourism Marketing, Developing Country, Indonesia JEL Classification: M3

\section{Introduction}

The economic impact of tourism appears to have escalated over the last ten years, as has been noted by the World Travel and Tourism Council (2018). It was reported that the tourism industry had supported more than 292 million jobs, and it had contributed to more than 10 per cent of the world's economy. Likewise, the tourism sector had been the backbone of Indonesia's economy for many years (Ministry of Tourism of the Republic of Indonesia, 2017). This industry had contributed to about 7.7 per cent of the country's GDP, an increase of 4.03 per cent from 2016 (World Travel and Tourism Council, 2018). It was also stated that the annual growth of foreign tourism in Indonesia had reached 15.54 per cent. In terms of employment opportunities, tourism had provided job prospects for about 11.7 million workers in 2016, accounting for 10 per cent of the total employment in Indonesia (Badan Pusat Statistik, 2017). The employment rate of Indonesia is expected to grow simultaneously with the tourism industry development. One of the steps taken by the Indonesian government in promoting tourism worldwide is through the "wonderful Indonesia" programmes. These programmes are anticipated to create more future opportunities for the country's tourism sector.

Considering the potential growth of Indonesia's tourism industry, it is important for the tourism operators and policy makers to understand the behaviour and the level of tourism satisfaction. This element has been found to have an impact on the visitors' intention to revisit a 
destination (Chen \& Tsai, 2007). Such efforts in studying visitors' satisfaction may help to sustain the future growth of the country's tourism. Although the tourism industry has been highlighted to be a fast-growing sector in many developing countries, its fast developments may not necessarily consider the sustainability issues. These issues, if not duly addressed, could impact both the environment and local communities, thereby curbing the future competitiveness of the industry (Cucculelli \& Goffi, 2016). This is because tourism activities exploit natural resources within the surroundings. Practical evidence (Aguiló, Alegre, \& Sard, 2005) indicates that having a sustainable tourism development not only prevents further deterioration; it could also contribute towards tourists' appreciation of the destinations visited. In relation to these arguments, the concept of green tourism, eco-friendly and preserved nature are highlighted as imperatives for sustainable tourism, especially tourism that is heavily dependent on the environment (Petrevska \& Cingoski, 2017). Without the green tourism approach, many tourism spots would lose their core values over time (Tang et al., 2017; Meler \& Ham, 2012; Xu, Cui, Sofield, \& Li 2014). Evidently, green tourism widens the prospects of the tourism sector. In his study, Beaumont (2011) asserted that tourists with a higher level of eco-awareness, tend to travel more frequently; they also play a significant role in the market which stresses on the importance of green tourism. Within the literature of green tourism (Choi, Parsa, Sigala, \& Putrevu, 2009; Kim, Njite, \& Hancer, 2013), a fair amount of research has been examining green consumer behaviour and the marketing of tourism products. Many studies have highlighted the contributions of sustainability from the perspective of green tourism marketing and some scholars (e.g. Hall, 2016; Lee, 2011) claimed that sustainable tourism is not confined to eco-friendly environments and the preservation of resources only, but also to other cultural, economic and social aspects.

Of late, the integration of creative industry into the tourism sector has led to the emergence of creative tourism, which provides immense opportunities for tourism operators to gain a competitive advantage (Rogerson \& Visser 2014; Tafel-Viia, Viia, Terk, \& Lassur, 2014; Waitt \& Gibson 2014). Unlike the common approach of visiting tourists' sites, creative tourism allows tourists to be involved in the activities of the attraction sites; it grants tourists the opportunity to participate in various events such as a performance or an interactive experience, both of which are expected to appeal to their satisfaction. The concept of creative tourism has been embraced in some developing countries, such 
as Asia, because it is seen as a contribution towards sustainable tourism (Richards, 2016; Maryunani \& Mirzanti, 2015). Yet, despite its emerging interest, there is a lack of studies focussing on how creative tourism affects the tourists' experience and satisfaction.

Motivated by this gap, the current study aims to examine the impact of green tourism marketing and creative industry towards tourism experience and satisfaction. This paper uses the Lake Toba tourists as samples to gather data for this study. Lake Toba is the largest natural lake in Indonesia. It is located in the middle of the northern part of Sumatera and is well known as the largest volcanic lake in the world. The Lake Toba region is one of the most well developed and well promoted area; it has been marketed by the Indonesian government as one of the most desirable tourism destinations throughout the world (Ratman, 2016). The main attraction of Lake Toba is the National Geopark of Danau Toba. Due to this, it is important for the Indonesian government to secure tourism sustainability in this particular region.

The rest of the discussion will be organised as follows. Section 2 discusses past literature on green tourism and creative tourism. It also highlights the hypotheses development. Section 3 explains the methodology employed while Section 4 reports on the results. Section 5 discusses the findings and Section 6 concludes the study by highlighting the impact of this study on theory and practice.

\section{Literature Review and Hypotheses Development}

\subsection{Green Tourism Marketing}

Green tourism is defined as the responsible way of travelling to natural areas in which tourists try to conserve the environment, as a means of maintaining sustainability of the environment (Lee, Honda, Ren, \& Lo, 2016). Green tourism is commonly associated with exotic, undisturbed and remote natural habitats such as rivers, parks, jungles, and other green spaces (Font \& Tribe, 2001). A properly developed green tourism destination can offer exciting experiences, which are seen as "rewarding", "enriching" and a "form of learning". The expansion of green tourism has been cultivated by developing countries since these countries possess tourism destinations that are susceptible to development (Sasidharan, Sirakaya, \& Kerstetter, 2002). Indonesia, for instance, hosts about 50 national parks, ranging from rain forests, endemic species, mountains, seas and rivers. Of these 50 national parks, six have 
been recognised as World Network of Biosphere Reserves. The diverse destinations of natural attractions in Indonesia serve as opportunities for the country to posit itself as a "green tourism" destination. Despite this, it is reported that the unavailable information and promotion about environmentally friendly and green destinations to tourists, is part of the problem in attracting the market segment.

Green tourism marketing could be referred to as the process of developing tourism products or services and promoting them in a way that does not result in any negative impact on the environment (Aggrawal, 2010). Similarly, the concept was defined by Ashrafi (2014) as an organisation's effort at designing, promoting, pricing and distributing products which are aligned with environmentally friendly practices. Therefore, green marketing can be used as a tool for sustainable growth. Dragićević, Jovičić, Blešić, Stankov and Bošković (2012) suggested that the concept of green tourism marketing entails:

\section{Core Resources}

These components involve the advantages of tourism destination, such as nature management or cultural heritage preservation.

2. Attractor

This component is related to the attraction of tourism destination from core resources, such as food attraction or festivals.

3. Supporting factor

This component is related to the government's support as well as the event organiser of the tourism destination. Supporting factors play a role in improving tourism management.

4. Amplifying determinant

This component is related to the superstructure and infrastructure, such as hotels, and security.

Green tourism marketing has been highlighted as an influential marketing strategy that boosts tourism purchasing behaviours, especially for tourists who value "sustainable environment". Literature (Delafrooz, Taleghani, \& Nouri, 2014; Delmas, Nairn-Birch, \& Balzarova, 2012; Furqan, Som, \& Hussin, 2010) seems to emphasise that many successful tourism operators such as leading hotel chains in developed countries are able to differentiate their products and services from competitors by repositioning themselves as "green". It was reported by Hsieh (2012) and Chan (2013) that hotel operators that are developing green marketing strategies to satisfy the needs of the environmentally 
conscious tourists, are on the increase. Their strategies include making use of ecolabels, certifications, awards and green alliances, as part of their green marketing campaigns. It was further indicated that rising consumers' concerns on environmental awareness has perhaps contributed to the movement towards the green marketing strategy. It appears that a successfully developed green tourism infrastructure might facilitate the tourism operators in creating a "green" image on aspects such as quality and attractiveness, which influence tourists' experiences. A positive image is created not only to increase the number of visits but also to provide a valuable experience to tourists. Based on these arguments, this study postulates that:

$\mathrm{H}_{1}$ : Green tourism marketing is positively related to tourism experiences.

$\mathrm{H}_{2}$ : Green tourism marketing is positively related to tourism satisfaction.

$\mathrm{H}_{3}$ : Tourism experiences mediate the relationship between green tourism marketing and tourism satisfaction.

\subsection{Creative Industry}

The tourism industry has always been associated with the consumption of culture, where people travel to learn more about others' cultures and civilisations. This suggests that culture provides the attraction that would help to generate tourism. Similarly, tourism would provide funding to support culture. This tourism trend, however, has been criticised, as it attracts large crowds whose visits might lead to the deterioration of the cultural sites. Such a problem has driven the emergence of a new niche tourism industry, termed as creative tourism (Fahmi, Koster, \& van Dijk, 2016). The development of creative tourism is partly driven by the influence of the creative industry.

A report from the Organisation for Economic Co-operation and Development (OECD, 2014) noted that there was a correlation between tourism activities and the presence of creative industry in tourism sites. This was also endorsed by Cruz (2014) who said that there is a positive relationship between creative industry and tourism. Creative industry has become the key source to breaking today's lock-in economic development. Today, the synergy between creative industry and tourism activities is getting the primary attention of various parties. There seems to be an urgent need to improve the social awareness of what creative 
industry can do for the local economy. In Indonesia, the term creative industry has been recognised since 2007, when the government started to realise the country's potential in culture and ideas, having a large pool of creative and artistic talents (Windarti, 2016). The term, creative industry, was then defined as those industries which have their origin in individual creativity, skill and talent, and which have the potential for wealth and job creation, through the generation and exploitation of intellectual property. Integrating creative industry into the tourism sector has propagated various tourism products and services which allow tourists to participate in different activities, such as crafts, arts, culinary and other creative activities. The presence of the creative industry in tourism can stimulate tourism growth in particular areas by creating a better tourism experience. Since the creative industry offers tourists the opportunity to learn new experiences and new skills, as well as the occasion to establish a close link with the local population and the cultural heritage of the specific destination, it is expected to be more fulfilling, thereby offering them new and memorable experiences (Wurzburger, Aageson, Pattakos, \& Pratt, 2010). Nonetheless, weaving creative industry into tourism requires efforts, such as the active participation and interaction of tourists instead of their mere presence of just "being there" (Jelincic \& Zuvela 2012; Richards, 2013).

Clearly, the concept of creative industry can cross the limits of the traditional tourism model; it can specifically benefit the tourism sector by providing tourists with the distinctive value of tourism; it revitalises local tourism products; it provides tourists with a more satisfying experience through creative technology and by constructing a more enjoyable atmosphere for tourists. All of these advantages will not only boost the tourists' experiences but also increase their satisfaction with the tourism destination. Korez-Vide (2013) had stressed that todays' tourists appear to want to become a part of the local community; they want to experience the local cultures, and they want to have an experience in living like the locals. With such an increasing interests for intangible experiences, this new tourism product, it is argued, will be able to satisfy the higher levels of the self-actualisation desires of tourists. Based on this, it is postulated that:

$\mathrm{H}_{4}$ : Creative industry is positively related to tourism experience.

$\mathrm{H}_{5}$ : Creative industry is positively related to tourism satisfaction.

$\mathrm{H}_{6}$ : Tourism experience mediates the relationship between creative industry and tourism satisfaction. 


\subsection{Tourism Experience and Satisfaction}

Tourism satisfaction has received considerable attention within the tourism literature. The notion of tourism satisfaction is defined as "tourists' perceptions on the products and services offered". It refers to the positive perception one feels; it is the satisfaction one has with the products, upon having used these products and services. In contrast, tourists will have a negative perception and feel unsatisfied if the reality they feel is below their expectations, upon consuming the products/ services. Three important dimensions are used to evaluate the level of customer or visitor satisfaction in consuming a service: (1) service satisfaction, (2) product satisfaction, and (3) price satisfaction (Kotler \& Keller, 2012). Various studies (Baker \& Crompton, 2000; Chi \& Qu, 2008; Gallarza \& Saura, 2006; Williams \& Soutar, 2009; Neal, Uysal, \& Sirgy, 2007; Sirgy, Kruger, Lee, \& Yu, 2011) have indicated that tourism satisfaction is important for sustaining the destination. These studies have established that satisfied tourists were more likely to repurchase the holiday package; they were also more likely to recommend such holiday packages to others. Tourists' positive holiday experiences will be translated into how they evaluate their satisfaction level. Tourism experiences can thus be referred to, "as the 'subjective mental state' perceived or felt by tourists during a service encounter" (Otto \& Ritchie, 1996, p. 166). The product of experience is highly valued by consumers because it can satisfy their spirit and offer them a memorable activity (Binkhorst, 2005; Murray, Foley, \& Lynch, 2010). A successful tourism experience will linger in the visitor's mind. Therefore, it is not merely a tourism trip but also the experience felt by tourists that will encourage the creation of tourism experience. Many previous researchers (Larsen, 2007; Poria, Butler, \& Airey, 2003; Uriely, Yonay, \& Simchai, 2002; Wickens, 2002) believed that tourism experience is subjective. In the green tourism context, for instance, tourists' interactions with the natural environment and amazing landscapes may provide joy to tourists, thereby resulting in an increased appreciation of the holiday destination (Poudel \& Nyaupane, 2013; Chen, Chen, \& Lee, 2011) and the reverse occurs for a negative experience. Based on this argument, it is postulated that:

$\mathrm{H}_{7}$ : Tourism experience is positively related to tourism satisfaction.

Following the outcomes noted in current literature, a research framework hypothesising green tourism marketing and creative indus- 


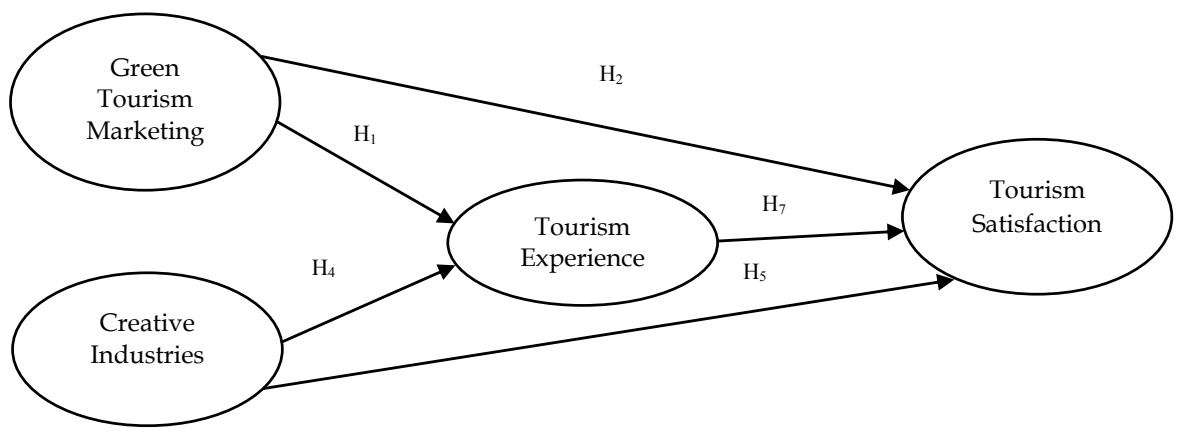

Figure 1: Research Framework

Note: $\mathrm{H}_{3}$ and $\mathrm{H}_{6}$ are the mediating effects.

try as predictors to tourism experience and satisfaction was developed. Tourism experience is also expected to mediate the relationship between green tourism marketing and creative industry with tourism satisfaction. Figure 1 illustrates.

\section{Research Methodology}

This study is quantitative in approach, it uses the questionnaire survey to collect data from tourists who had visited Lake Toba for their destination. The constructs for the questionnaire are adapted from previous literature and then tailored to the context of this study. Following Dragićević et al. (2012), this study defines green tourism marketing as promotional activities of tourism products/services in a way that does not result in any negative impact on the environment. The concept of green tourism is measured based on four aspects: core resources, attractor, supporting factor and amplifying determinant. Thirteen items are used to measure this construct. Seven items are based on the Ministry of Trade of the Republic of Indonesia's (2009) idea of creative industry. This concept assesses the extent tourism operators are able to project tourism destinations as a creative tourism spot. Tourism experience is then assessed based on tourists' experience during their stay at the tourism destination. This study assess the tourism experience based on six components, which include: lifestyle, cultural heritage, landscape, art, tradition and culture, and interactions with the local community. These items are adapted from Murray et al. (2010). Tourism 
satisfaction is based on the satisfaction level perceived by the tourists upon the consumption of the product/service provided. This evaluation is based on three aspects: service, tourism product and price.

The focus of this study is given to Lake Toba in Indonesia because it is the government's focus for preserving the natural and cultural creativity of the surrounding communities. Lake Toba has also been promoted as a geopark tourist area, and has been prioritised by the Indonesian government (Ministry of Tourism of the Republic of Indonesia, 2015) for development and promotion. Using a purposive sampling method, we distributed 220 questionnaires to the tourists at different destination spots, hotels and restaurants at the Lake. As we expected that there would be overseas respondents, we prepared questionnaires in Bahasa and English. Consent are taken before we distribute the questionnaires. The survey is distributed at different times of the day over two weeks, during public holidays in Indonesia. The selected resort hotels had similar quality ratings. Of these 220 questionnaires, 200 were returned. Table 1 illustrates further.

Table 1: Respondents' Profile

\begin{tabular}{lcr}
\hline Characteristics & Number of Participants & Percentage (\%) \\
\hline Based on Origin & 176 & 88 \\
$\quad$ North Sumatera & 0 & 0 \\
Outside North Sumatera & 24 & 12 \\
Foreign Countries & & \\
Sex & 136 & 68 \\
Male & 64 & 32 \\
Female & & \\
\hline
\end{tabular}

As can be seen, 88 per cent of the respondents are from North Sumatera whilst only 12 per cent are from foreign countries, such as India, the Netherlands, Australia and Singapore. This figure indicates that most of the tourists who visited Lake Toba are local tourists. As expected, majority of the respondents are males (68\%). Although the tourism products offered by the Lake Toba destination are not specifically designed for any particular gender, the nature around the Samosir Island is more popular among males, especially those who like to camp. Looking at the products and services, it appears that the 


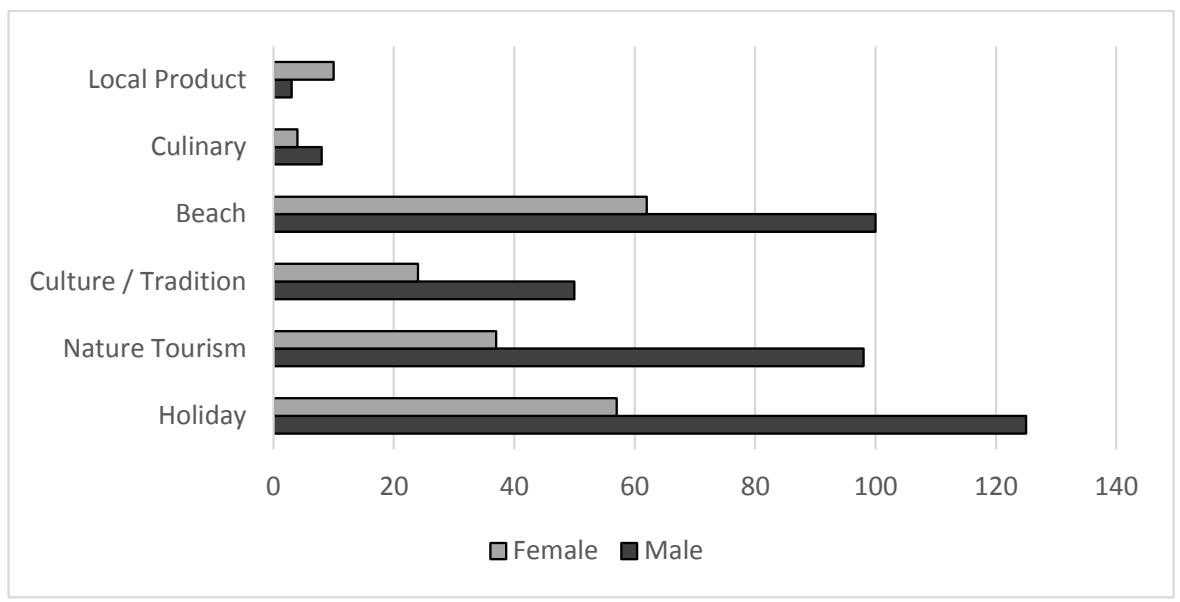

Figure 2: Tourism Purpose

tourists are more interested in Lake Toba as a holiday destination. They appear to choose the destination due to its nature and beaches, as compared to its creative industry. Only a few respondents take the tour for culinary purposes or for the local products. The main purpose of their visit is to relax, obtain the tourism experience and rebuild their memory with friends (Figure 2).

\section{Result and Discussion}

\subsection{Confirmatory Factor Analysis Model Evaluation}

This study performs a confirmatory factor analysis (CFA) to validate the psychometric properties of the measurements. This is done by examining the convergent validity, and discriminant validity. The convergent validity is assessed through the factor loadings, composite reliability and average variance extracted. Table 2 illustrates.

As indicated in Table 2, all the items have factor loadings of more than 0.6 (Chin, 1998). The composite reliability for all the constructs is above the recommended value $(0.902-0.949)$ and the AVE values for all constructs are above 0.5 (Hair, Hult, Ringle, \& Sarstedt, 2016). This study also assesses the discriminant validity based on Fornell and Larcker's (1981) criterion. The results of the discriminant validity test are presented in Table 3. 
Table 2: Convergent Validity

\begin{tabular}{lccc}
\hline Variable/Construct & $\begin{array}{c}\text { Factor } \\
\text { Loadings }\end{array}$ & $\begin{array}{c}\text { Composite } \\
\text { Reliability }\end{array}$ & $\begin{array}{c}\text { Average Variance } \\
\text { Extracted }\end{array}$ \\
\hline Green Tourism Marketing & & 0.949 & 0.590 \\
Core Resource 1 & 0.740 & & \\
Core Resource 2 & 0.724 & & \\
Core Resource 3 & 0.783 & & \\
Attractor 1 & 0.711 & & \\
Attractor 2 & 0.881 & & \\
Attractor 3 & 0.814 & & \\
Attractor 4 & 0.735 & & \\
Supporting Factor 1 & 0.808 & & \\
Supporting Factor 2 & 0.762 & & \\
Supporting Factor 3 & 0.762 & & \\
Amplifier 1 & 0.725 & & \\
Amplifier 2 & 0.821 & & \\
Amplifier 3 & 0.695 & & \\
\hline Creative Industries & & & \\
Local Product & 0.763 & & \\
Souvenir & 0.713 & & \\
Central Market & 0.632 & & \\
Cultural Value Product & 0.808 & & \\
Unique Advertisement & 0.838 & & \\
Product Development & 0.759 & & \\
Musical Imbued Product & 0.752 & & \\
\hline Tourism Experience & & & \\
Lifestyle 1 & 0.729 & & \\
Lifestyle 2 & 0.685 & & \\
Heritage 1 & 0.870 & & \\
Heritage 2 & 0.679 & & \\
Scenery 1 & 0.705 & & \\
Scenery 2 & 0.602 & & \\
Cultural 1 & 0.613 & & \\
Cultural 2 & 0.648 & & \\
Tradition 1 & 0.717 & & \\
Tradition 2 & 0.645 & & \\
Local Interaction 1 & 0.915 & & \\
Local Interaction 2 & 0.618 & & \\
\hline
\end{tabular}


Table 2: (continued)

\begin{tabular}{lccc}
\hline Variable/Construct & $\begin{array}{c}\text { Factor } \\
\text { Loadings }\end{array}$ & $\begin{array}{c}\text { Composite } \\
\text { Reliability }\end{array}$ & $\begin{array}{c}\text { Average Variance } \\
\text { Extracted }\end{array}$ \\
\hline Tourism Satisfaction & & 0.928 & 0.566 \\
Overall Satisfaction 1 & 0.671 & & \\
Overall Satisfaction 2 & 0.663 & & \\
Overall Satisfaction 3 & 0.835 & & \\
Cost-Benefit Satisfaction 1 & 0.856 & & \\
Cost-Benefit Satisfaction 2 & 0.880 & & \\
Cost-Benefit Satisfaction 3 & 0.689 & & \\
Service Satisfaction 1 & 0.716 & & \\
Service Satisfaction 2 & 0.610 & & \\
Service Satisfaction 3 & 0.893 & & \\
Service Satisfaction 4 & 0.643 & & \\
\end{tabular}

Table 3: Discriminant Validity

\begin{tabular}{lcccc}
\hline Variables & $\begin{array}{c}\text { Green Tourism } \\
\text { Marketing }\end{array}$ & $\begin{array}{c}\text { Creative } \\
\text { Industries }\end{array}$ & $\begin{array}{c}\text { Tourism } \\
\text { Experience }\end{array}$ & $\begin{array}{c}\text { Tourism } \\
\text { Satisfaction }\end{array}$ \\
\hline $\begin{array}{l}\text { Green Tourism } \\
\quad \text { Marketing }\end{array}$ & $\mathbf{0 . 7 6 8}$ & & & \\
Creative Industry & 0.195 & $\mathbf{0 . 7 5 5}$ & & \\
Tourism Experience & 0.491 & 0.421 & $\mathbf{0 . 7 0 8}$ & \\
Tourism Satisfaction & 0.501 & 0.681 & 0.401 & $\mathbf{0 . 7 5 3}$ \\
\hline
\end{tabular}

As shown in Table 3, all the constructs appear to have the square root of the AVE that is higher than the correlations with other variables. This highlights the achievement of the discriminant validity (Fornell \& Larcker, 1981). In total, the measurement model demonstrates the adequate convergent and discriminant validity.

\subsection{Structural Model Analysis}

Assuming that the measurement model satisfies the psychometric assessment, a structural model is constructed. Table 4 and Figure 3 present the results of the hypotheses testing. The examination of the hypotheses is based on the t-value, where a value greater than 1.96, represents 


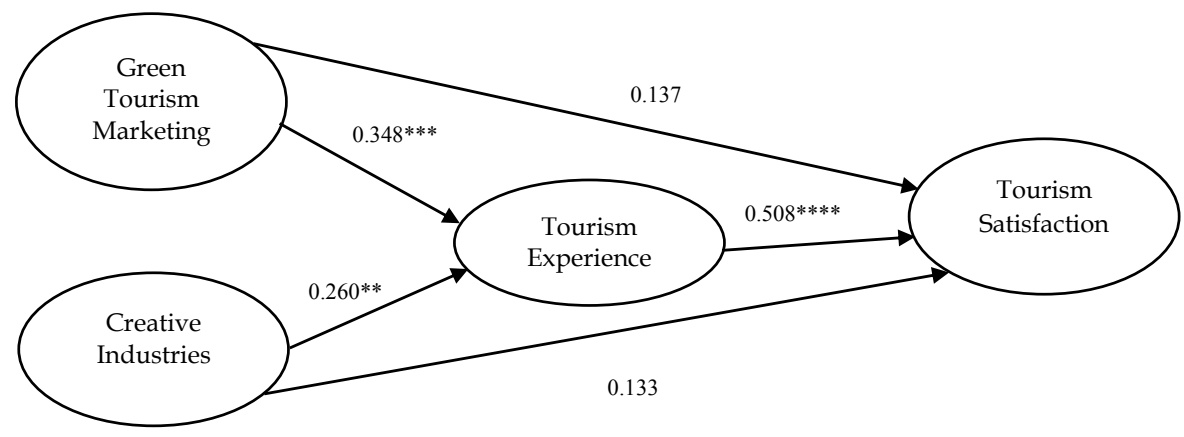

Figure 3: Structural Model Analysis

Table 4: Hypothesis Testing

\begin{tabular}{llccc}
\hline $\begin{array}{l}\text { Hypo- } \\
\text { theses }\end{array}$ & \multicolumn{1}{c}{ Path } & $\begin{array}{c}\text { Path } \\
\text { Coefficient }\end{array}$ & p-value & Decision \\
\hline $\mathrm{H}_{1}$ & $\begin{array}{l}\text { Green tourism marketing } \rightarrow \\
\text { tourism experience }\end{array}$ & 0.348 & 0.000 & Accept \\
$\mathrm{H}_{2}$ & $\begin{array}{l}\text { Green tourism marketing } \rightarrow \\
\text { tourism satisfaction } \\
\text { *Green tourism marketing } \rightarrow \\
\text { tourism experience } \rightarrow \text { tourism } \\
\text { satisfaction }\end{array}$ & 0.137 & 0.112 & Reject \\
& $\begin{array}{l}\text { Creative industry } \rightarrow \text { tourism } \\
\text { experience }\end{array}$ & $0.177^{*}$ & 0.002 & Accept \\
$\mathrm{H}_{4}$ & $\begin{array}{l}\text { Creative industry } \rightarrow \text { tourism } \\
\text { satisfaction } \\
\mathrm{H}_{5}\end{array}$ & 0.133 & 0.002 & Accept \\
$\mathrm{H}_{6} \quad \begin{array}{l}\text { *Creative industry } \rightarrow \text { tourism } \\
\text { experience } \rightarrow \text { tourism satisfaction }\end{array}$ & $0.132^{*}$ & 0.008 & Accept \\
$\mathrm{H}_{7} \quad \begin{array}{l}\text { Tourism experience } \rightarrow \text { tourism } \\
\text { satisfaction }\end{array}$ & 0.508 & 0.000 & Accept \\
\hline
\end{tabular}

Note: *Indirect effect, generated from PLS report.

a significant path. The results indicate that green tourism marketing affects tourism experiences $(\beta=0.348, \mathrm{p}<0.001)$, hence supporting $\mathrm{H}_{1}$. The effect of creative industry on tourism experience is found to be positively significant $(\beta=0.26, \mathrm{p}<0.05)$. Therefore, $\mathrm{H}_{4}$ is also supported. Surprisingly, in this study, green tourism marketing $(\beta=0.137, p=$ 
$0.112)$ and creative industry $(\beta=0.133, p=0.11)$ are found to have no significant effect on tourism satisfaction. Therefore, $\mathrm{H}_{2}$ and $\mathrm{H}_{5}$ are not supported. As expected, tourism experience has a significant effect on tourism satisfaction $(\beta=0.508, \mathrm{p}<0.001)$, thereby supporting $\mathrm{H}_{7}$. While the direct effect of green tourism marketing and creative industry on tourism satisfaction are insubstantial, the effect of these two dimensions on tourism satisfaction, through tourism experiences, appeared to have a significant effect, thereby supporting $\mathrm{H}_{3}$ and $\mathrm{H}_{6}$.

\section{Discussion}

This study has investigated the relationship among green tourism marketing, creative industry, tourism experience and tourism satisfaction. The outcome derived from this study demonstrates that green tourism marketing and creative industry serve as crucial factors in arousing tourism experience. Yet, the direct impact of these two dimensions on tourism satisfaction is not substantial. These two dimensions would only affect tourism satisfaction, with the existence of tourism experience. The role of tourism experience as a mediator, in this study, facilitates in explaining how tourism operators could use tourism experience as a tool to cultivate tourism satisfaction.

In this study, green tourism marketing is found to have a significant effect on tourism experience, in the context of Lake Toba as a destination. The findings indicate that the Lake Toba tourists can be influenced by green tourism marketing. Thus, efforts should be concentrated to bring forth green tourism marketing so as to promote better tourism experience. Tourists who are more sensitive to environmental issues have their own notion of enjoying tourism by maintaining natural preservation. It is important to classify them as an important tourism market (Beaumont, 2011). This is also argued by Lee et al. (2016) who asserted that green tourism could serve as a stimulation to tourists because they are given an environmental-friendly vacation. The findings of this study are consistent with those of previous studies. The current study shows that there is a positive and significant effect of green tourism on tourism experience. The existence of green tourism has further stimulated tourists' experience. The preservation of nature and its authentic natural values can make tourism experience more exciting. Green tourism marketing, therefore, would be able to enhance tourism satisfaction, but only if its practices succeed in promoting better tourism experience. 
In line with previous studies (Christian \& Elena, 2015; Cruz, 2014), this study finds that the presence of creative industry encourages the creation of better tourism experience. The presence of creative industry in Lake Toba is a supporting factor in creating better tourism experience. The use of technology and culture in presenting creative tourism will encourage better tourism experience. The result of this study also indicates that authentic tourism experiences, which are developed outside the regular tourism product offerings, are valuable. The opportunities offered to tourists to experience the landscape, the local community, the local culture and food enhances tourists experiences. Nonetheless, this study also found that the creative industry alone, does not promote tourism satisfaction, in the context of Lake Toba. It appears that creative industry or creative tourism needs to create tourism experience which can then enhance tourism satisfaction. This shows that tourists' evaluation on their tourism and travel acitivites, are entirely based on their tourism experiences. Satisfaction, either based on tourism products, services, or the amount of money spent to get the tourism experience, is evaluated as interesting tourism experience sources.

Tourism experience is the biggest contributor for achieving tourism satisfaction. Previous research had applied various approaches to evaluate tourism experience, such as by using the emotional approach (Prayag, Hosany, Muskat, \& Del Chiappa, 2017), visitors' activities (Armario, 2008), and tourism experience sources (Murray et. al., 2010). These approaches connect tourism experience and tourism satisfaction. In accordance with previous research, tourism experience has a positive effect on tourism satisfaction. The experience felt by the visitors would be evaluated by their own consideration. Lovelock and Wirtz (2011) had explained that satisfaction would be experienced when what is felt by people is in accordance with what they expect. In the tourism context, visitors would be satisfied in their tourism experience when what they get is equal to or more than that of their tourism expectations, whether in terms of service, product, or expenses.

\section{Conclusion and Implications}

The findings gained from this study will be able to contribute to the body of literature on tourism in a number of ways. First, this study extends the knowledge on how green tourism marketing and creative industry are related to tourism satisfaction in the context of Lake Toba, Indonesia. Although extensive literature has provided evidence on how 
green tourism marketing can help to sustain the tourism industry, it is not clear how the integration of creative industry into the tourism sector would benefit the operators. The findings generated from the current study show that many tourists who visited Lake Toba tend to report a higher level of satisfaction with the products and services offered when the holiday package is able to promote a good and memorable tourism experience. Thus, it would seem practical for Indonesia, as a developing country, to make attempts to integrate the concept of creative industry into its tourism sector as one contribution towards sustainable tourism. There is evidence drawn from this study to show that tourism satisfaction can only be achieved by improving the overall tourism experience. The key factor in creating tourism satisfaction is by creating exciting tourism experiences for visitors.

The results of this study imply that marketers involved in promoting Lake Toba as a holiday destination need to consider the strategic role of tourism experience in arousing tourism satisfaction. They also need to strategically enhance their green marketing communications. Similarly, the marketing strategy needs to translate the promotion as a positive tourism experience so that maximum benefits can be reaped. It is only through this approach that the sustainability of Lake Toba as a holiday destination can be assured. Green marketing strategies can be improved and accomplished by continually modifying them according to the needs of potential tourists. The outcome of this study indicates that tourism operators need to be creative in finding ways of designing innovative products which can be offered to prospective visitors so as to enable them to experience the local culture, local foods and the local community. This is important for the tourism operators as they match tourists' needs with products/services offered, thereby enabling visitors to have enjoyable and memorable vacations.

Despite the fact that the current study has provided some useful insights into the role of creative industry and green tourism marketing on tourism experience and satisfaction in the context of Lake Toba, Indonesia, there are also some limitations that need to be addressed. The first of these is the generalisability of the results which has focused on tourists who visited Lake Toba. Future research may need to consider gathering data from several other holiday destinations in other countries, for the sake of comparison. The second limitation is that the survey is confined to only a few variables. Thus, it would be interesting for future research to incorporate more variables that are related to sustainable tourism industry within the Asian context. 


\section{References}

Aggrawal, A. (2010). Factors affecting green marketing in India: A study of metro consumers (Master thesis, Patil University, India). Retrieved from http:// www.dypatil.edu/schools/management/wp-content/uploads/2015/05/ Factors-Affecting-Green-Marketing-In-India-A-Study-Of-Metro-ConsumersArtee-Agarwal-.pdf

Aguiló, E., Alegre, J., \& Sard, M. (2005). The persistence of the sun and sand tourism model. Tourism Management, 26(2), 219-231. http://dx.doi.org/ 10.1016/j.tourman.2003.11.004

Armario, E.M. (2008). Tourist satisfaction: An analysis of its antecedents. Annals of Tourism Research, 21(4), 844-846.

Ashrafi, M. (2014). Green marketing in hospitality industry. Journal of Applied Environmental and Biological Sciences, 4(4), 42-46.

Badan Pusat Statistik (2017). Indonesia dalam angka. Jakarta: Author.

Baker, D.A., \& Crompton, J.L. (2000). Quality, satisfaction and behavioral intentions. Annals of Tourism Research, 27(3), 785-804. http://dx.doi.org/ 10.1016/S0160-7383(99)00108-5

Beaumont, N. (2011). The third criterion of ecotourism: Are ecotourists more concerned about sustainability than other tourists? Journal of Ecotourism, 10(2), 135-148. http:/ / dx.doi.org/10.1080/14724049.2011.555554

Binkhorst, E. (2005). The co-creation tourism experience. Sitges: Whitepaper Co Creations.

Chan, E.S.W. (2013). Gap analysis of green hotel marketing. International Journal of Contemporary Hospitality Management, 25(7), 1017-1048. http://dx.doi. org/10.1108/IJCHM-09-2012-0156

Chen, C-F., \& Tsai, DC. (2007). How destination image and evaluative factors affect behavioral intentions? Tourism Management, 28(4), 1115-1122. http:/ / dx.doi.org/10.1016/j.tourman.2006.07.007

Chen, C-M., Chen, S.H., \& Lee, H.T. (2011). The destination competitiveness of Kinmen's tourism industry: Exploring the interrelationships between tourist perceptions, service performance, customer satisfaction and sustainable tourism. Journal of Sustainable Tourism, 19(2), 247-264. http:// dx.doi.org/10.1080/09669582.2010.517315

Chi, C.G.Q., \& Qu, H. (2008). Examining the structural relationships of destination image, tourist satisfaction and destination loyalty: An integrated approach. Tourism Management, 29(4), 624-636. http://dx.doi.org/10.1016/ j.tourman.2007.06.007

Chin, W.W. (1998). The partial least squares approach to structural equation modeling. In G.A. Marcoulides (Ed.), Methodology for business and management: Modern methods for business research (pp. 295-336). Mahwah, NJ: Lawrence Erlbaum Associates Publishers.

Choi, G., Parsa, H.G., Sigala, M., \& Putrevu, S. (2009). Consumers' environmental concerns and behaviors in the lodging industry: A comparison between 
Greece and the United States. Journal of Quality Assurance in Hospitality $\mathcal{E}$ Tourism, 10(2), 93-112. http:/ / dx.doi.org/10.1080/15280080902946335

Christian, S., \& Elena, R. (2015). Creative tourism in destination brand identity. International Journal Vallis Aurea, 1(1), 75-83.

Cruz, A.R. (2014). Tourism, creativity and talent: Breaking Algarve's tourism lock-in. Regional Studies, Regional Science, 1(1), 138-144. http:/ /dx.doi.org/1 $0.1080 / 21681376.2014 .939529$

Cucculelli, M., \& Goffi, G. (2016). Does sustainability enhance tourism destination competitiveness? Evidence from Italian destinations of excellence. Journal of Cleaner Production, 111(Part B), 370-382. http://dx.doi. org/10.1016/j.jclepro.2014.12.069

Delafrooz, N., Taleghani, M., \& Nouri, B. (2014). Effect of green marketing on consumer purchase behavior. QScience Connect, 1(March). http://dx.doi. org/10.5339/connect.2014.5

Delmas, M., Nairn-Birch, N., \& Balzarova, M. (2012). Lost in a sea of green: Navigating the eco-label labyrinth (Working paper, Institute of the Environment and Sustainability). Los Angeles, CA: UCLA.

Dragićević, V., Jovičić, D., Blešić, I., Stankov, U., \& Bošković, D. (2012). Business tourism destination competitiveness: A case of Vojvodina Province (Serbia). Economic Research / Ekonomska Istraživanja, 25(2), 311-331. http:/ / dx.doi.org/10.1080/1331677X.2012.11517510

Fahmi, F.Z., Koster, S., \& van Dijk, J. (2016). The location of creative industries in a developing country: The case of Indonesia. Cities, 59(November), 66-79. http:/ / dx.doi.org/10.1016/j.cities.2016.06.005

Font, X., \& Tribe, J. (2001). Promoting green tourism: The future of environmental awards. International Journal of Tourism Research, 3(1), 9-21. http:/ / dx.doi. org/10.1002/1522-1970(200101/02)3:1\%3C9::AID-JTR244\%3E3.0.CO;2-Q

Fornell, C., \& Larcker, D.F. (1981). Evaluating structural equation models with unobservable variables and measurement error. Journal of Marketing Research, 18(1), 39-50. http:/ / dx.doi.org/10.1177\%2F002224378101800104

Furqan, A., Mat Som, A.P, \& Hussin, R. (2010). Promoting green tourism for future sustainability. Theoretical and Empirical Researches in Urban Management, 5(8), 64-74.

Gallarza, M.G., \& Saura, I.G. (2006). Value dimensions, perceived value, satisfaction and loyalty: An investigation of university students' travel behaviour. Tourism Management, 27(3), 437-452. http://dx.doi.org/10.1016/ j.tourman.2004.12.002

Hair, J.J.F., Hult, G.T.M., Ringle, C.M., \& Sarstedt, M. (2016). A primer on partial least squares structural equation modeling (PLS-SEM). Thousand Oaks, CA: Sage Publications.

Hall, C.M. (2016). Intervening in academic interventions: Framing social marketing's potential for successful sustainable tourism behavioural change. Journal of Sustainable Tourism, 24(3), 350-375. http:/ /dx.doi.org/10.1080/09 669582.2015.1088861 
Hsieh, Y-C. (2012). Hotel companies' environmental policies and practices: A content analysis of their web pages. International Journal of Contemporary Hospitality Management, 24(1), 97-121. http:/ / dx.doi.org/10.1108/095961112 Jelincic, D.A., \& Žuvela, A. (2012). Facing the challenge? Creative tourism in Croatia. Journal of Tourism Consumption and Practice, 4(2), 78-90.

Kim, Y.J., Njite, D., \& Hancer, M. (2013). Anticipated emotion in consumers' intentions to select eco-friendly restaurants: Augmenting the theory of planned behavior. International Journal of Hospitality Management, 34(September), 255-262. http:/ / dx.doi.org/10.1016/j.ijhm.2013.04.004

Korez-Vide, R. (2013). Promoting sustainability of tourism by creative tourism development: How far is Slovenia? Innovative Issues and Approaches in Social Sciences, 6(1), 77-102.

Kotler, P.T., \& Keller, K.L. (2012). Marketing management (14th Ed.). Upper Saddle River, NJ: Prentice Hall.

Larsen, S. (2007). Aspects of a psychology of the tourist experience. Scandinavian Journal of Hospitality and Tourism, 7(1), 7-18. http://dx.doi.org/ $10.1080 / 15022250701226014$

Lee, T.H. (2011). How recreation involvement, place attachment and conservation commitment affect environmentally responsible behavior. Journal of Sustainable Tourism, 19(7), 895-915. http://dx.doi.org/10.1080/09669582. 2011.570345

Lee, S-M, Honda, H.C., Ren, G., \& Lo, Y-C. (2016). The implementation of green tourism and hospitality. Journal of Tourism \& Hospitality, 5(4), 233-237. http://dx.doi.org/10.4172/2167-0269.1000233

Lovelock, C.H., \& Wirtz, J. (2011). Services marketing: People, technology, strategy (7th Ed.). New York, NY: Prentice Hall.

Maryunani, S.R., \& Mirzanti, I.R. (2015). The development of entrepreneurship in creative industries with reference to Bandung as a creative city. Procedia - Social and Behavioral Sciences, 169(January), 387-394. http://dx.doi. org/10.1016/j.sbspro.2015.01.324

Meler, M., \& Ham, M. (2012). Green marketing for green tourism. Paper presented at the Conference on Tourism \& Hospitality Industry: New Trends in Tourism and Hospitality Management, Opatija, May, 2012.

Ministry of Tourism of the Republic of Indonesia. (2015). Accountability report: Ministry of Tourism performance 2014. Indonesia: Author.

Ministry of Tourism of the Republic of Indonesia. (2017). Accountability report: Ministry of Tourism performance 2016. Indonesia: Author.

Ministry of Trade of the Republic of Indonesia. (2009). Creative industries in Indonesia 2009. Jakarta: Author.

Murray, N., Foley, A., \& Lynch, P. (2010). Understanding the tourist experience concept. Ireland: Waterford Institute of Technology.

Neal, J.D., Uysal, M., \& Sirgy, M.J. (2007). The effect of tourism services on travelers' quality of life. Journal of Travel Research, 46(2), 154-163. http:/ / dx.doi.org/10.1177\%2F0047287507303977 
OECD (2014). Tourism and the creative economy. OECD Studies on Tourism. Austria: OECD Publishing. http:/ /dx.doi.org/10.1787/9789264207875-en

Otto, J.E., \& Ritchie, J.B. (1996). The service experience in tourism. Tourism Management, 17(3), 165-174. http:/ / dx.doi.org/10.1016/0261-5177(96)00003-9

Petrevska, B., \& Cingoski, V. (2017). Branding the green tourism in Macedonia. Sociology and Space, 55(1), 101-116. http:/ /dx.doi.org/10.5673/sip.55.1.5

Poria, Y., Butler, R., \& Airey, D. (2003). The core of heritage tourism. Annals of Tourism Research, 30(1), 238-254. http://dx.doi.org/10.1016/S0160-7383(02) 00064-6

Poudel, S., \& Nyaupane, G.P. (2013). The role of interpretative tour guiding in sustainable destination management: A comparison between guided and nonguided tourists. Journal of Travel Research, 52(5), 659-672. http:/ / dx.doi. org/10.1177\%2F0047287513478496

Prayag, G., Hosany, S., Muskat, B., \& Del Chiappa, G. (2017). Understanding the relationships between tourists' emotional experiences, perceived overall image, satisfaction, and intention to recommend. Journal of Travel Research, 56(1), 41-54. http:/ / dx.doi.org/10.1177\%2F0047287515620567

Ratman, D.R. (2016). Development of priority tourism destination 2016-2019. Jakarta, Indonesia: Ministry of Tourism.

Richards, G. (2013). Tourism development trajectories - From culture to creativity? In M. Smith \& G. Richards (Eds.), Routledge Handbook of Cultural Tourism (pp. 297-303). New York, NY: Routledge.

Richards, G. (2016). The challenge of creative tourism. Ethnologies, 38(1-2), 31-45. http:/ / dx.doi.org/10.7202/1041585ar

Rogerson, C.M., \& Visser, G. (2014, December). A decade of progress in African urban tourism scholarship. Urban Forum 25(4), 407-417. http://dx.doi. org/10.1007/s12132-014-9238-0

Sasidharan, V., Sirakaya, E., \& Kerstetter, D. (2002). Developing countries and tourism ecolabels. Tourism Management, 23(2), 161-174. http://dx.doi. org/10.1016/S0261-5177(01)00047-4

Sirgy, M.J., Kruger, P.S., Lee, D-J., \& Yu, G.B. (2011). How does a travel trip affect tourists' life satisfaction? Journal of Travel Research, 50(3), 261-275. http:/ / dx.doi.org/10.1177\%2F0047287510362784

Tafel-Viia, K., Viia, A., Terk, E., \& Lassur, S. (2014). Urban policies for the creative industries: A European comparison. European Planning Studies, 22(4), 796-815. http:/ / dx.doi.org/10.1080/09654313.2013.772755

Tang, C., Zheng, Q., Qin, N., Sun, Y., Wang, S., \& Feng, L. (2017). A review of green development in the tourism industry. Journal of Resources and Ecology, 8(5), 449-459. http:/ / dx.doi.org/10.5814/j.issn.1674-764x.2017.05.002

Uriely, N., Yonay, Y., \& Simchai, D. (2002). Backpacking experiences: A type and form analysis. Annals of Tourism Research, 29(2), 520-538. http:/ / dx.doi. org/10.1016/S0160-7383(01)00075-5

Waitt, G.R., \& Gibson, C.R. (2014). Tourism and creative economies. In A. Lew, C. Hall, \& A.M. Williams (Eds.), Wiley Blackwell Companions to Geography: 
Wiley Blackwell Companion to Tourism (pp. 230-239). Chichester: WileyBlackwell. http://dx.doi.org/10.1002/9781118474648.ch18

Wickens, E. (2002). The sacred and the profane: A tourist typology. Annals of Tourism Research, 29(3), 834-851. http://dx.doi.org/10.1016/S0160-7383(01) 00088-3

Williams, P., \& Soutar, G. N. (2009). Value, satisfaction and behavioral intentions in an adventure tourism context. Annals of Tourism Research, 36(3), 413-438. http://dx.doi.org/10.1016/j.annals.2009.02.002

Windarti, Y. (2016). Communities inclusion of urban tourism development: The case of Bandung City, Indonesia. International Journal of Culture and History, 2(4), 189-198. http://dx.doi.org/10.18178/ijch.2016.2.4.062

World Travel and Tourism Council. (2018). Travel and tourism global economic impact and issues 2018. United Kingdom: Author.

Wurzburger, R., Aageson, T., Pattakos, A. \& Pratt, S. (2010). Creative tourism: A global conversation. Santa Fe, New Mexico: Sunstone Press.

Xu, H., Cui, Q., Sofield, T., \& Li, F.M.S. (2014). Attaining harmony: Understanding the relationship between ecotourism and protected areas in China. Journal of Sustainable Tourism, 22(8), 1131-1150. http://dx.doi.org/ 10.1080/09669582.2014.902064 